\title{
AUTOLOGOUS AND HOMOLOGOUS TRANSFUSION OF HUMAN ASCITIC FLUID
}

\author{
By H. A. DAVIS ANd J. F. BLALOCK, JR. \\ (From the Department of Pathology, University of Tennessee, Memphis)
}

(Received for publication November 29, 1938)

The physiological availability of the individual intravenous solutions which have been used for experimental and clinical purposes varies. In secondary shock where an oligemia exists the value of protein-containing infusions is evident. Gum-acacia saline solutions, used for the first time in human beings by Hurwitz (1), were administered extensively in traumatic shock during the World War (2). However, certain complications may follow the administration of gumacacia solutions such as, liver damage (3), interference with plasma protein regeneration (4), and a reduction in the oxygen content of the blood (5). This has affected to some extent its general popularity. Gelatin-saline solutions have been recommended $(6,7)$ for the treatment of shock, but have fallen into disuse due to the fact that the gelatine leaves the blood stream very rapidly and, therefore, maintains the blood pressure for only a short period of time. Solutions of hemoglobin are capable of carrying oxygen and maintaining the osmotic pressure of the blood for a short period of time $(8,9)$. The hemoglobin is soon converted into methemoglobin resulting in renal damage during its excretion (10). However, hemoglobin in Ringer's solutions can maintain life in the mammal provided a minimum of intracellular hemoglobin remains in the blood stream of the experimental animal $(8,9)$. The hemoglobin in Ringer's solution, for obvious reasons, has not been used in the human.

The first use of blood plasma and serum for transfusion purposes was made in the lower mammals by Guthrie and Pike (11). The hemoconcentration of the blood in various forms of shock provides a rational basis for the transfusion of blood plasma and blood serum. Excellent results have been reported following their administration in man $(12,13)$. The difficulty in obtaining blood from the usual sources has led to the use of blood from the placenta (14), the umbilical cord (15), and the cadaver (16).
The search for a blood substitute has induced us to determine the effectiveness of human pleural and peritoneal transudates (ascitic fluid). In a previous study upon the heterologous transfusion of ascitic fluid, it has been demonstrated to be of value as a substitute for blood in experimental shock in animals (17). In the present investigation, autologous and homologous transfusions of human ascitic fluid have been performed, with special reference to their effects from the viewpoint of toxicity, transfusion reactions, and effects upon blood pressure, pulse rate, and urine.

\section{Properties of human ascitic fluid}

Quantitative chemical examinations of a series of ascitic fluids revealed the following figures per $100 \mathrm{cc}$. of fluid : total protein, 2.0 to 3.19 grams; albumin, 0.96 to 1.9 grams; globulin, 0.6 to 0.8 gram; fibrinogen, 0.2 to 0.41 gram; nonprotein nitrogen, 18 to $40 \mathrm{mgm}$.; sodium chloride, 700 to $750 \mathrm{mgm}$.; and calcium 6.8 to $7.8 \mathrm{mgm}$. The albumin: globulin ratio ranged from $1.1: 1$ to $2.3: 1$. It will be seen that the protein content of ascitic fluid is approximately 28 per cent to 45 per cent that of blood plasma. It has been demonstrated that the osmotic pressure of the interstitial fluids of the body follows closely that of plasma of the blood (18) which suggests that the osmotic pressure of ascitic fluid is approximately that of blood plasma.

A prerequisite to the successful homologous and heterologous transfusion is the determination of the grouping of the fluid. This has been shown conclusively in animals (17). It has been pointed out that group specific agglutinins are present in peritoneal and pleural transudates $(19,20)$. Such substances are similar to those occurring in the blood. These facts render imperative the determination of the compatability of the fluid with the blood of the prospective recipient. In support of the necessity for such determinations are the transfusion deaths resulting in several animals from the use of incompatible ascitic fluid. Ac- 
cordingly, cross agglutination tests were performed throughout this investigation.

\section{Heterologous transfusion of ascitic fluid}

A brief recapitulation of the results of transfusion of ascitic fluid in dogs may be pertinent at this point. It has been recognized previously that group specific substances are present in the lower animals, e.g., in dogs $(21,22)$. By the performance of cross agglutination tests it was found that human ascitic fluid could be transfused, with safety, into dogs (17). No toxic effects were noted. Secondary shock was then produced by graded hemorrhage. The administration of the fluid was capable of raising the blood pressure from the shock level. The urine remained consistently free from albumin suggesting that the proteins of the fluid were utilized by the animals.

\section{METHODS}

In these studies both pleural and peritoneal transudates were available. However, in most instances ascitic fluid obtained from human patients suffering from portal cirrhosis of the liver or cardiac decompensation was used. The fluids were removed with aseptic precautions and stored in sterile flasks at a temperature of 0 to $5^{\circ} \mathrm{C}$. No preservatives were used and bacteriological examinations were made at intervals using the blood-agar plate method. Prolonged refrigeration did not affect the physiological availability of human ascitic fluid (17). Each fluid was submitted to the following examinations: Kahn test, blood agar culture, and determination of the protein and electrolyte content. The Kahn and Wassermann tests were performed upon the blood of the donor of the fluid. Immediately before use, the fluid was filtered through six layers of fine gauze and heated to body temperature in a water bath.

A group of nine patients was selected to demonstrate the result of the autologous and homologous transfusion of human ascitic fluid. Cross agglutination tests (23) were carried out between the ascitic fluid and the blood of the prospective recipient which was diluted with 0.85 per cent sodium chloride solution. Two drops of ascitic fluid and one drop of diluted blood were used for each examination. In order to exclude the possible existence of an allergic sensitiveness to the fluid, an intradermal injection of $0.5 \mathrm{cc}$. of the ascitic fluid was made into the recipient. In none of the patients of the present series was the presence of such a sensitiveness noted. The fluid was administered intravenously by gravity at a rate of $10 \mathrm{cc}$. per minute. The usual aseptic precautions were taken. The amount of fluid which was administered varied from 500 to $1500 \mathrm{cc}$. All of these patients had been hospitalized for varying periods prior to the infusion so that a basal level of blood pressure and pulse rate had already been attained. The blood pressure and pulse rate were determined before and during the introduction of the fluid. Urinary examinations were carried out before and after the transfusions.

\section{Transfusion of ascitic fluid in humans}

The autologous and homologous transfusion of ascitic fluid was studied with particular reference to the effect upon blood pressure (Table I). It will be noticed that the effect upon the systolic and the diastolic pressures varies. The systolic pressure remains unchanged or shows a depression of several $\mathrm{mm}$. $\mathrm{Hg}$ which is then followed by a slight elevation of blood pressure. In other instances, the systolic blood pressure did not alter. The diastolic pressure, however, showed an early increase of a few $\mathrm{mm}$. $\mathrm{Hg}$ and a slight depression later. On the other hand, an early depression of the diastolic blood pressure was seen occasionally. Examination of the blood pressure one hour after the completion of the transfusion revealed an approximate return to the pretransfusion level. These results suggest that the transfusion of ascitic fluid in individuals with relatively normal blood pressures, has only a slight effect in elevating the blood pressure. This is in accordance with the well known fact that infusions in individuals with normal blood pressures yield only a mild and temporary pressor effect. Later, the transfusion of ascitic fluid in one case of traumatic shock will be described.

TABLE I

Influence of homologous transfusion of human ascitic fluid upon blood pressure

\begin{tabular}{|c|c|c|c|c|c|c|c|}
\hline \multirow{3}{*}{ Case } & \multicolumn{7}{|c|}{ Blood pressure } \\
\hline & \multirow{2}{*}{$\begin{array}{l}\text { Before } \\
\text { trans- } \\
\text { fusion }\end{array}$} & \multicolumn{5}{|c|}{ After transfusion } & \multirow{2}{*}{$\begin{array}{l}1 \text { hour } \\
\text { later }\end{array}$} \\
\hline & & $\begin{array}{l}100 \\
\text { cc. }\end{array}$ & $\begin{array}{l}200 \\
\text { cc. }\end{array}$ & $\begin{array}{l}300 \\
\text { cc. }\end{array}$ & $\begin{array}{l}400 \\
\text { cc. }\end{array}$ & $\begin{array}{l}500 \\
\text { cc. }\end{array}$ & \\
\hline $\begin{array}{l}\text { G. } \\
\text { G. } \\
\text { M. } \\
\text { M. } \\
\text { W. B. } \\
\text { C. W. } \\
\text { G.. } \\
\text { G. S. }\end{array}$ & $\begin{array}{c}\underset{\mathrm{mm} .}{\mathrm{mg}} \\
142 / 100 \\
114 / 68 \\
124 / 70 \\
96 / 60 \\
132 / 66 \\
130 / 96 \\
140 / 48 \\
108 / 76 \\
136 / 82\end{array}$ & $\begin{array}{c}\text { mm. } \\
H g \\
142 / 96 \\
114 / 72 \\
124 / 70 \\
92 / 60 \\
130 / 62 \\
126 / 86 \\
148 / 52 \\
108 / 76 \\
134 / 72\end{array}$ & $\begin{array}{c}\underset{H m}{\operatorname{mm}} \\
\text { Hg } \\
142 / 112 \\
116 / 72 \\
122 / 76 \\
96 / 62 \\
126 / 62 \\
132 / 88 \\
146 / 50 \\
112 / 80 \\
138 / 74\end{array}$ & $\begin{array}{c}\text { mm. } \\
H g \\
142 / 110 \\
114 / 74 \\
122 / 74 \\
92 / 62 \\
128 / 56 \\
132 / 92 \\
142 / 58 \\
114 / 76 \\
136 / 76\end{array}$ & $\begin{array}{c}\text { mm. } \\
H g \\
144 / 96 \\
116 / 80 \\
122 / 74 \\
96 / 64 \\
130 / 58 \\
130 / 94 \\
142 / 56 \\
116 / 76 \\
134 / 76\end{array}$ & $\begin{array}{c}\text { mm. } \\
H g \\
152 / 110 \\
118 / 80 \\
122 / 72 \\
98 / 62 \\
130 / 58 \\
132 / 94 \\
142 / 58 \\
114 / 76 \\
136 / 76\end{array}$ & $\begin{array}{c}150 / 108 \\
118 / 80 \\
122 / 72 \\
98 / 62 \\
132 / 60 \\
132 / 92 \\
158 / 60 \\
118 / 82 \\
150 / 84\end{array}$ \\
\hline
\end{tabular}

The effect upon the pulse rate is also variable. In some patients there is present a slowing of the pulse, and in others an acceleration takes place. The reason for this is not clear. Exam- 
ination of the urine revealed a transient cloudiness which persisted for several days following the transfusion. However, the usual tests for albumin were consistently negative. No evidences could be found of glycosuria or hematuria. These facts suggest that the ascitic fluid does not injure the kidneys and that the proteins of the fluid are utilized by the recipient.

The incidence of post-transfusion reactions was low, only two occurring out of a total of ten transfusions. This low incidence is emphasized by the fact that the ascitic fluid which was used had been subjected to a prolonged refrigeration lasting from three to five months. Both reactions were of a mild character, consisting of a brief rigor and moderate rise of temperature. No other untoward symptoms were observed. One of these patients was febrile prior to the transfusion and, therefore, more susceptible to a reaction.

The question now arises as to the possibility of the occurrence of shock from the autologous retransfusion of ascitic fluid. It has been pointed out that homologous retransfusion shock can take place, and that, in dogs, this is of an anaphylactic nature (24). In one patient, J. B., a second transfusion of his own ascitic fluid ten days after the primary transfusion produced no evidences of shock. Evidently, this patient had not developed any allergic sensitiveness to his own protein.

\section{Ascitic fluid transfusion in traumatic shock}

The experimental evidence of the efficacy of ascitic fluid in treatment of hemorrhagic shock in animals (17) suggested its use in clinical secondary shock. One patient in this series, A. H., was admitted to the John Gaston Hospital in a severe state of secondary shock resulting from a gunshot wound of the abdomen. At the time he was seen by one of us (H. A. D.), he had been in shock for a period of approximately 12 hours. The usual evidences of grave secondary shock were present-profuse sweating, restlessness, rapid feeble pulse, hypotension, slow sighing respirations, and semiconsciousness. Previous treatment which had included two infusions of isotonic glucose solution had proved ineffective in raising the blood pressure. Blood of the appropriate type was not available. Human ascitic fluid of the correct type was obtained and a transfusion of $1500 \mathrm{cc}$. of fluid was given. It will be noted (Figure 1) that the blood pressure which was $66 / 44$ at the commencement of the transfusion rose gradually to $104 / 70$. The objective

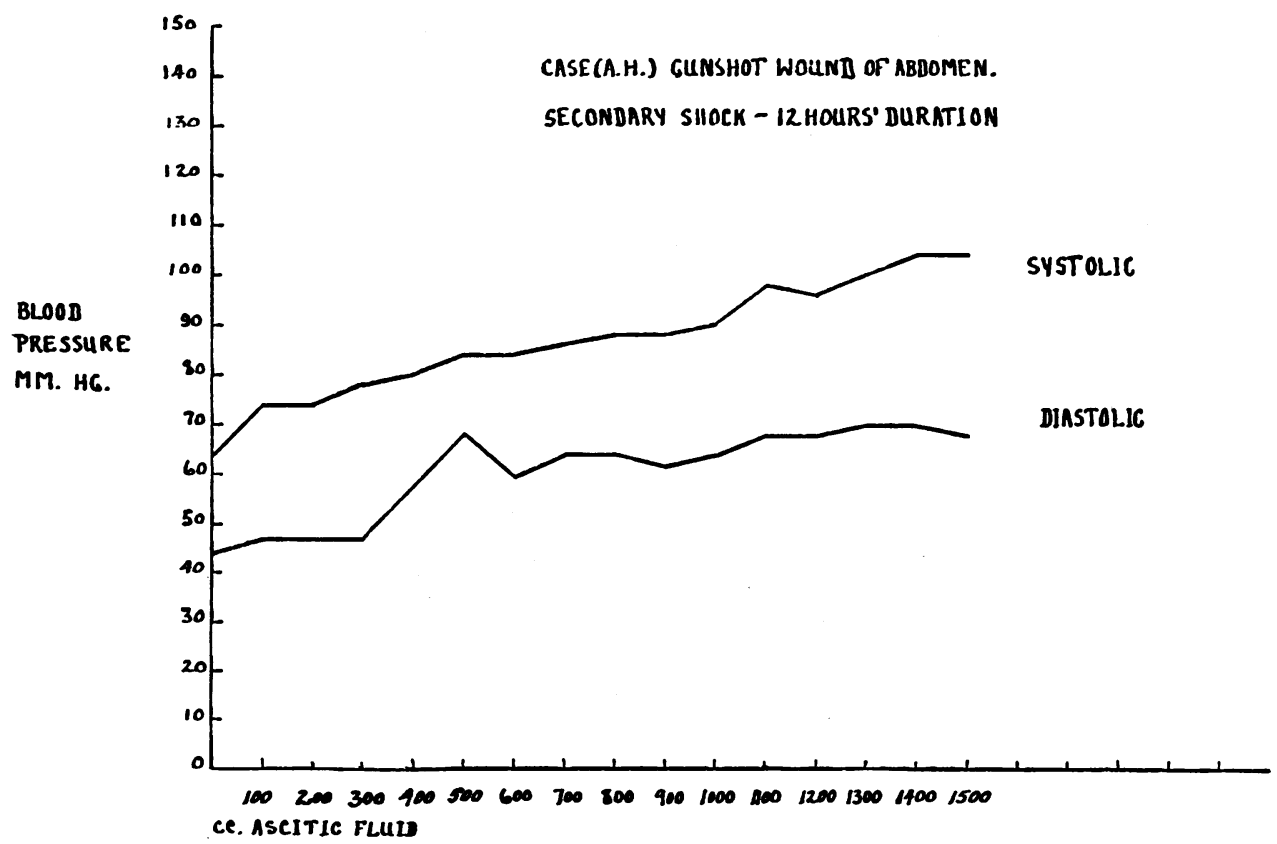

Fig. 1. Influence of Ascitic Fluid Transfusion in Traumatic Shock 
signs of shock diminished to a corresponding extent. At this time an exploratory laparotomy was performed. During the operation the systolic blood pressure fell to $70 \mathrm{~mm}$. $\mathrm{Hg}$ but a second transfusion of ascitic fluid raised it to $100 \mathrm{~mm}$. $\mathrm{Hg}$. The patient finally succumbed 36 hours later. This case is of interest from two viewpoints. First, this patient received $2500 \mathrm{cc}$. of ascitic fluid without any deleterious effects. Secondly, while the ascitic fluid elevated the blood pressure where previous infusions had failed to do so, this elevation of blood pressure was not maintained.

\section{CASE REPORTS}

J. G.: male, white, 33 years. Diagnosis: lipoid nephrosis of 3 years' duration: two transfusions of ascitic fluid, one of $500 \mathrm{cc}$. and the other $1000 \mathrm{cc}$; no evidences of reaction.

T. W.: male, white, 32 years. Diagnosis: chronic alcoholism of 10 years' duration: one transfusion of 500 cc. of ascitic fluid; no evidences of reaction.

$W$. B.: male, white, 44 years. Diagnosis : tertian malaria of 3 weeks' duration: one transfusion of $500 \mathrm{cc}$. of ascitic fluid. No evidences of reaction.

$R$. M.: female, white, 31 years. Diagnosis : syphilis of central nervous system: one transfusion of $500 \mathrm{cc}$. of ascitic fluid: mild rigor followed transfusion, and temperature rose from 94 to $102.4^{\circ} \mathrm{F}$.

L. B.: female, colored, 46 years. Diagnosis : tertiary syphilis: one transfusion of $500 \mathrm{cc}$. of ascitic fluid: no evidenses of reaction.

$M$. L.: female, colored, 36 years. Diagnosis : epidermoid carcinoma of cervix uteri of 1 year's duration. One transfusion of $500 \mathrm{cc}$. of ascitic fluid; mild rigor and rise of temperature to $102^{\circ} \mathrm{F}$. followed by rapid recovery

$J$. B.: male, colored, 55 years. Diagnosis : portal cirrhosis of liver with ascites. One transfusion of $1000 \mathrm{cc}$. of his own ascitic fluid: no reaction. Ten days later a second transfusion of $100 \mathrm{cc}$. of his own fluid was given without any evidences of reaction.

$H$. $M$.: male, colored, 40 years. Diagnosis : gun-shot wound of abdomen. One transfusion of $500 \mathrm{cc}$. of ascitic fluid; no evidences of reaction.

A. H.: male, colored, 41 years. Diagnosis: gun-shot wound of abdomen with severe secondary shock. Two transfusions of ascitic fluid, the first being $1500 \mathrm{cc}$. and the second, $1000 \mathrm{cc}$. The first transfusion raised the systolic blood pressure from 64 to $104 \mathrm{~mm}$. Hg. The second transfusion raised the systolic blood pressure from 70 to $100 \mathrm{~mm}$. Hg. Blood of appropriate type was not available, and the final outcome was death in deep shock 36 hours after admission to the hospital.

\section{COMMENTS}

In a survey of the results of ascitic fluid transfusion, it becomes apparent that this fluid is not toxic in human beings provided that the proper precautions are taken. In only two of the entire group of transfusions did there occur reactions, and these could have been avoided probably by a more thorough filtration of the fluid. It is our belief that the cause of these reactions was particulate matter which had escaped filtration. Bacterial contamination as a source of the reactions can be excluded in view of the care taken to avoid this factor. Denaturation of the fluid proteins by prolonged refrigeration is an unlikely possibility, although it cannot be definitely excluded as yet. In all of the fluids a varying amount of fibrin clotting takes place. This spontaneous defibrination may render the fluid slightly toxic.

It might be pertinent, at this point, to review the question of vasotonins in the fluid. Such vasotonins have been described in whole blood, blood serum, and blood plasma $(25,26,27)$. These vasotonins are of two types, one being vasoconstrictor in character, and the other vasodilator. The vasoconstrictor substances are both temporary and permanent in nature $(28,29,30)$. The vasodilator substances are present in fresh serum and plasma but usually disappear after refrigeration. The dilator substances have been analyzed and, apparently, are proteins (25) and are related to adenosine phosphoric acid (31). It has been pointed out that these vasotropic substances are present in all of the body fluids, including ascitic fluid (32). For this reason, it is important to consider the possibility of such substances being the cause of certain of the reactions to ascitic fluid transfusion. The changes in pressure following the use of serum and plasma has been ascribed by many to the presence of particulate matter which can be removed by repeated filtration. However, this mechanical theory cannot be reconciled with the fact that ergotamine prevents the pressor effect of serum and plasma extracts $(27,33)$.

How adequate, from a physiological standpoint, are blood plasma and serum in the replacement of whole blood? The concentration of erythrocytes in traumatic shock and in shock following burns suggests that the major cause of the oligemia is the loss of the fluid portion rather than the cellular portion of the blood from the vascular system. Further proof of this lies in the fact that the transfusion of blood plasma and blood serum has proven successful in the secondary shock of ex- 
perimental animals $(11,34,35,36,37,38)$ and of human beings $(2,12,13)$.

For this reason, it would seem to be logical to assume that the transfusion of ascitic fluid might be of value in conditions of shock associated with a concentration of the red blood cells.

The lower protein content of ascitic fluid as compared with that of blood presents a further problem for solution. The concentration of ascitic fluid and its preservation in a "lyophile" form is being carried out by the method described by Flosdorf and Mudd (39). It is proposed to study the effects of this "lyophile" form of ascitic fluid in secondary shock. Lyophile serum has been used with promising results in experimental shock (40) and in clinical shock (41). However, severe reactions may follow the use of concentrated serum in animals (42) and in human beings $(40,41)$.

\section{CONCLUSION}

The transfusion of human ascitic fluid in groupcompatible animal and human recipients is practicable. Reactions are few and relatively mild and, probably, will be eliminated by more thorough filtration of the fluid. Prolonged refrigeration does not affect the physiological availability of ascitic fluid. It is suggested that the value of the fluid may be enhanced by concentration. The properties of the concentrated or lyophile form of ascitic fluid are being investigated.

We wish to express our deep appreciation to Dr. J. L. McGehee, Chairman of the Department of Surgery, and to Dr. J. B. McElroy, Chairman of the Department of Medicine, for their kindness in making available patients on their services for this study.

\section{BIBLIOGRAPHY}

1. Hurwitz, S. H., Intravenous injections of colloidal solutions of acacia in hemorrhage. Preliminary note. J. A. M. A., 1917, 68, 699.

2. Robertson, O. H., and Bock, A. V., Memorandum on blood volume after haemorrhage. Special Report Series, Med. Res. Com., London, 1918, 25, 213.

3. Dick, M. W., Warweg, E., and Andersch, M., Acacia in treatment of nephrosis. J. A. M. A., 1935, 105, 654.

4. Hall, W. K., The effects of intravenous injections of acacia upon certain functions of the liver. Am. J. Physiol. (Proc.), 1938, 123, 88.

5. Christie, A., Phatak, N. M., and Olney, M. B., Effect of intravenous acacia on physico-chemical proper- ties of the blood. Proc. Soc. Exper. Biol. and Med., 1935, 32, 670.

6. Hogan, J. J., The intravenous use of colloidal (gelatin) solutions in shock. J. A. M. A., 1915, 64, 721.

7. Clark, G. W., Effects of intravenous injections of a colloid (gelatin) upon rabbit sera. J. Immunol., 1918, 3, 147.

8. Amberson, W. R., Mulder, A. G., Steggerda, F. R., Flexner, J., and Pankratz, D. S., Mammalian life without red blood corpuscles. Science, 1933, 78, 106.

9. Green, A. A., Studies in the physical chemistry of the proteins. $\mathrm{X}$. The solubility of hemoglobin in solutions of chlorides and sulfates of varying concentration. J. Biol. Chem., 1932, 95, 47.

10. Bayliss, L. E., Kerridge, P. M. T., and Russell, D. S., The excretion of protein by the mammalian kidney. J. Physiol., 1933, 77, 386.

11. Guthrie, C. C., and Pike, F. H., The relation of the activity of the excised mammalian heart to pressure in the coronary vessels and to its nutrition. Am. J. Physiol., 1907, 18, 14.

12. Richet, C., Brodin, P., and Saint-Girons, F., Des injections de plasma sanguin (plasmothérapie) pour remplacer le sang total. Compt. rend. Acad. d. sc., $1918,167,618$.

13. Filatov, A., and Kartaševskij, N., Die Transfusion von menschlichem Blutplasma als blutstillendes Mittel. Zentralbl. f. Chir., 1935, 62, 441.

14. Malinovskij, M. S., Smirnova, L. G., Boyarshinova, M. S., and Tarzanova, V. G., Use of placental blood in transfusion. Sovet. khir., 1934, 7, 179.

15. Novikova, L. A., and Farberova, R. S., Organization of collection and use of umbilical cord blood for transfusion. Sovet. khir., 1936, 11, 794.

16. Judine, S., La transfusion du sang de cadavre à l'homme. Masson, Paris, 1933.

17. Davis, H. A., and White, C. S., Human ascitic fluid as a blood substitute in experimental secondary shock. Proc. Soc. Exper. Biol. and Med., 1938, 38, 462.

18. Gilman, A., and Cowgill, G. R., Osmotic relations between blood and body fluids. IV. Pancreatic juice, bile and lymph. Am. J. Physiol., 1933, 104, 476.

19. Emile-Weil, P., and Isch-Wall, P., Hémo-agglutinines des divers liquides organiques. Compt. rend. Soc. de biol., 1923, 88, 173.

20. Yosida, K. I., Über die gruppenspezifischen Unterschiede der Transsudate, Exsudate, Sekrete, Exkrete, Organextrakte und Organzellen des Menschen und ihre rechtsmedizinischen Anwendungen. Ztschr. f. d. ges. exper. Med., 1928, 63, 331.

21. von Dungern, E., and Hirschfeld, L., Ueber gruppenspezifische Strukturen des Blutes. Ztschr. f. Immunitätsforsch. u. exper. Therap., 1911, 8, 526.

22. Thomsen, O., and Kemp, T., Blutgruppendifferenzierung bei Tieren. I. Ztschr. f. Immunitätsforsch. u. exper. Therap., 1930, 67, 251. 
23. Coca, A. F., The examination of the blood preliminary to the operation of blood transfusion. J. Immunol., 1918, 3, 93.

24. Melnick, D., and Cowgill, G. R., Differentiation of blood groups in dogs based on antigenic complexes present in the erythrocytes. Proc. Soc. Exper. Biol. and Med., 1937, 36, 697.

25. Stewart, H. A., and Harvey, S. C., The vasodilator and vasoconstrictor properties of blood serum and plasma. J. Exper. Med., 1912, 16, 103.

26. Meyer, O. B., Untersuchungen über die vaskonstriktorischen Eigenschaften des Blutserums. Ztschr. f. Biol., 1925, 82, 400.

27. Bayliss, L. E., and Ogden, E., "Vasotonins" and the pump-oxygenator-kidney preparation. J. Physiol. (Proc.), 1933, 77, 34 P.

28. Goldberger, S., Ricerche sulla Labilità della Sostanza vasocostrittrice del Siero. Boll. Soc. ital. Biol. sper., 1931, 6, 827.

29. Goldberger, S., Sulla Duplicità della Sostanza vasocostrittrice del Siero. Arch. di fisiol., 1932, 31, 381.

30. Janeway, T. C., Richardson, H. B., and Park, E. A., Experiments on the vasoconstrictor action of blood serum. Arch. Int. Med., 1918, 21, 565.

31. Zipf, K., Die chemische Natur der "depressorischen Substanz" des Blutes. Arch. f. exper. Path. u. Pharmakol., 1931, 160, 579.

32. Page, I. H., Pressor substances from the body fluids of man in health and disease. J. Exper. Med., $1935,61,67$.

33. Heymans, C., Bouckaert, J. J., and Moraes, A., Inversion per l'ergotamine de l'action vasoconstrictrice des "vasotonines" du sang défibriné. Arch. internat. de pharmacodyn. et de thérap., 1932, 43, 468.
34. Foster, D. P., and Whipple, G. H., Blood fibrin studies. III. Fibrin values influenced by transfusion, haemorrhage, plasma depletion and blood pressure changes. Am. J. Physiol., 1922, 58, 393.

35. Weech, A. A., Goettsch, E., and Reeves, E. B., The effect of serum transfusion on the plasma protein depletion associated with nutritional edema in dogs. J. Clin. Invest., 1933, 12, 217.

36. Rossius, L., Ein tierexperimenteller Beitrag zur Frage der Bluttransfusion. Arch. f. klin. Chir., 1925, 137, 583.

37. Kallius, H. M., Die Verweildauer der gebräuchlichen Blutersatzflüssigkeiten, insbesondere transfundierten Serums, nach grossen Blutverlusten im Tierexperiment. Deutsche Ztschr. f. Chir., 1929, 220, 216.

38. Mann, F. C., Further experimental study of surgical shock. J. A. M. A., 1918, 71, 1184.

39. Flosdorf, E. W., and Mudd, S., Procedure and apparatus for preservation in "lyophile" form of serum and other biological substances. J. Immunol., 1935, 29, 389.

40. Bond, D. D., and Wright, D. G., Treatment of haemorrhage and traumatic shock by the intravenous use of lyophile serum. Ann. Surg., 1938, $107,500$.

41. Mahoney, E. B., A study of experimental and clinical shock with special reference to its treatment by the intravenous injection of preserved plasma. Ann. Surg., 1938, 108, 178.

42. Achard, C., Lévy, J., and Gallais, F., Recherches expérimentales sur quelques modifications colloïdales produites dans le sérum sanguin par l'injection de sérum concentré et par les saignées plasmatiques. Compt. rend. Acad. d. sc., 1932, 194, 1773. 